\title{
Liver X Receptor Agonist T0901317 Prevents Diacylglycerols Accumulation in the Heart of Streptozotocin-Diabetic Rats
}

\author{
Dorota Harasiuk Marcin Baranowski Piotr Zabielski Adrian Chabowski \\ Jan Górski
}

Department of Physiology, Medical University of Białystok, Białystok, Poland

\author{
Key Words \\ Myocardium • Fatty acids $•$ DAG $•$ Cardiac muscle $•$ Nuclear receptors $•$ Type 1 diabetes
}

\begin{abstract}
Background/Aims: Liver X receptors ( $L X R \alpha$ and $L X R \beta)$ are ligand-activated transcription factors that regulate expression of genes involved in lipid and cholesterol metabolism. LXR expression has been identified in the heart, and enhanced LXR activity in the streptozotocin (STZ) diabetic myocardium was reported recently. The aim of this study was to investigate effect of in vivo LXR activation on myocardial lipid metabolism under conditions of STZ-induced diabetes. Methods: Wistar rats were randomly divided into three experimental groups: non-diabetic control, treated with STZ, and treated with STZ and LXR agonist - TO901317. Diabetes was induced by a single intraperitonal injection of STZ at a dose of $55 \mathrm{mg} / \mathrm{kg}$. LXR agonist was administrated once daily in the morning by an oral gavage at a dose of $10 \mathrm{mg} / \mathrm{kg} / \mathrm{d}$ during the last week of the experiment. After anesthesia samples of blood and the left ventricle were taken. Results: TO901317 administration increased expression of both LXR isoforms and its target genes: sterol response element binding protein 1c (SREBP-1c) and acetyl-coenzyme A carboxylase 1 (ACC1) in the heart of streptozotocin-diabetic rats. Treatment with LXR agonist had no effect on plasma lipids and glucose in the diabetic rats. Concomitantly, content of the examined lipid classes in the diabetic heart (nonesterified fatty acids, triacylglycerols, phospholipids, cholesterol esters, ceramide) was unchanged after treatment with T0901317. On the contrary, myocardial level of cholesterol and diacylglycerols (DAG) was decreased after LXR activation in diabetic rats, the change in DAG level was associated with downregulated expression of adipose triglyceride lipase (ATGL). Conclusion: Activation of LXRs by TO901317 protects cardiomyocytes against DAG accumulation and thus may reverse disturbances in lipid metabolism observed in streptozotocin-diabetic heart.
\end{abstract}

\section{Introduction}

Liver X receptor (LXR) $\alpha$ and $\beta$, are ligand-activated transcription factors that belong to the nuclear receptor superfamily [1]. LXR $\alpha$ is expressed predominantly in tissues with high 


\section{Cellular Physiology Cell Physiol Biochem 2016;39:350-359 \\ \begin{tabular}{c|c|c|c|} 
DOI: 10.1159/000445629 & Ond Biochemistry \\
Published online: June 29, 2016 & $\begin{array}{l}\text { 2016 The Author(s). Published by S. Karger AG, Basel } \\
\text { www.karger.com/cpb }\end{array}$
\end{tabular} \\ Harasiuk et al.: TO901317 Prevents Diacylglycerols Accumulation in the Diabetic Heart}

level of lipid metabolism, such as liver, adipose tissue, intestine, kidney and macrophages, whereas LXR $\beta$ is expressed ubiquitously in all examined tissues [2]. Upon ligand-induced activation both isoforms form heterodimers with retinoid X receptor (RXR), and the LXR/ RXR complex binds to the LXR response element (LXRE) in the promoter region of the target genes and their transcription is stimulated [3]. Physiological ligands of LXRs are oxysterols, which are oxygenated derivatives of cholesterol [4]. Synthetic LXR agonists T0901317 and GW3965, are commonly used in experimental studies, and they activate both LXR isoforms with similar potency [3]. LXR activation induces transcription of genes involved in the efflux, transport and excretion of cholesterol [5]. In addition, synthetic LXR agonists stimulate hepatic lipogenesis by induction of expression of SREBP-1c, which results in liver steatosis and hypertriglyceridemia [6,7]. LXR expression has been identified also in the rodent cardiac tissue, and LXR $\beta$ is the dominant isoform [2, 8-11].

Type 1 diabetic heart is characterized by loss of flexibility in using different types of energy substrates and is forced to oxidize fatty acids because of absence of insulin and lower rates of cardiac glucose uptake [12]. Moreover, fatty acids are more available to the heart because of increased lipolysis in adipose tissue, which is normally inhibited by insulin [13]. The excessive availability of lipids and fatty acids may exceed the rate of their use by the heart, resulting in increased myocardial long chain fatty acyl-CoA concentrations [14]. Long chain fatty acyl-CoAs can be utilized for the synthesis of DAG and ceramide, lipid intermediates that are considered to be toxic [14]. As a consequence of these changes, cardiac function gradually declines, and finally is manifested as diabetic cardiomyopathy [12].

Lipids are energy substrates for cardiomyocytes, they are components of cell membranes, precursors of signaling molecules, and ligands for nuclear transcription factors. Their myocardial metabolism is disturbed in type 1 diabetes because of insulin deficiency. LXRs are transcriptional regulators of lipid metabolism in various tissues and cells [15]. Therefore, the aim of this study was to investigate if LXR activation with the synthetic agonist T0901317 prevents disturbances in lipid metabolism observed in streptozotocin-diabetic heart.

\section{Materials and Methods}

\section{Animals}

The investigation was approved by the Ethical Committee for Animal Experiments at the Medical University of Białystok (permit no. 35/2008). Male Wistar rats (approximately $200 \mathrm{~g}$ body weight) were housed under controlled conditions $\left(21^{\circ} \mathrm{C} \pm 1,12 \mathrm{~h}\right.$ light $/ 12 \mathrm{~h}$ dark cycle, light on at 06:00 am) with free access to standard rodent chow and water. The animals were randomly divided into three groups $(\mathrm{n}=10 \mathrm{in}$ each group): (1) non-diabetic control, (2) treated with streptozotocin, (3) treated with streptozotocin and T0901317. Diabetes was induced by a single intraperitonal injection of streptozotocin (Sigma) dissolved in citric buffer $(\mathrm{pH}=4,5)$ at a dose of $55 \mathrm{mg} / \mathrm{kg}$. Dual $\mathrm{LXR} \alpha / \beta$ agonist T0901317 (Cayman Chemicals) suspended in $0,5 \%$ carboxymethylcellulose was administrated once daily in the morning by an oral gavage at a dose of $10 \mathrm{mg} / \mathrm{kg} / \mathrm{d}$ during the last week of the experiment. Three weeks after administration of streptozotocin, and $24 \mathrm{~h}$ after the last T0901317/vehicle administration, all rats were anaesthetized by intraperitoneal injection of pentobarbital in the dose of $80 \mathrm{mg} / \mathrm{kg}$ (in the fed state). Blood taken from the abdominal aorta was collected in heparinized tubes, centrifuged, the plasma separated and flash-frozen in liquid nitrogen. Next samples of the left ventricle were excised and immediately freeze-clamped with aluminum tongs precooled in liquid nitrogen. All samples were stored at $-80^{\circ} \mathrm{C}$ until analysis.

\section{Myocardial lipids}

Ventricular samples were pulverized in an aluminum mortar precooled in liquid nitrogen. Lipids were extracted by the method of Folch. The fractions of total phospholipids, triacylglycerols (TAG), DAG, nonesterified fatty acids (NEFA), free cholesterol and cholesterol esters were separated by thin-layer chromatography according to Roemen and van der Vusse [16]. Lipid were then transmethylated in either $1 \mathrm{M}$ methanolic sodium methoxide (Fluka) at room temperature for 10 minutes (TAG and phspholipids) or 


\section{Cellular Physiology Cell Physiol Biochem 2016;39:350-359 \begin{tabular}{c|c|c|} 
DOI: 10.1159/000445629 & O 2016 The Author(s). Published by S. Karger AG, Basel \\
wwww.karger.com/cpb
\end{tabular} \\ Harasiuk et al.: TO901317 Prevents Diacylglycerols Accumulation in the Diabetic Heart}

$14 \%$ methanolic boron trifluoride (Sigma) at $100^{\circ} \mathrm{C}$ for either 2 (NEFA) or 10 (DAG) minutes. The content of resulting fatty acid methyl esters was determined using gas-liquid chromatography as previously described [17]. Free cholesterol and cholesterol esters were eluted from the gel with chloroform, evaporated under nitrogen stream and redissolved in 2-propanol or diethyl ether, respectively. The content of free cholesterol and cholesterol esters was subsequently measured with commercially available cholesterol diagnostic kit (BioMaxima). The content of ceramide was determined as previously described [18]. Briefly, tissue lipids were extracted into chloroform and the samples were then subjected to alkaline hydrolysis to deacylate ceramide. Free sphingosine liberated from ceramide was converted to o-phthalaldehyde derivative and analyzed using HPLC system. N-palmitoyl-D-erythrosphingosine (C17 base) was used as an internal standard.

\section{Real-time PCR}

Total RNA was isolated from 50mg of frozen tissue using Total RNA (A\&A Biotechnology) according to the producer's instructions. First strand cDNA was generated using High Capacity cDNA Reverse Transcription Kit (Applied Biosystem) according to the producer's instructions. Real-time PCR was performed with specific primers (for primer sequences see Table 1) and SYBR Green JumpStart Taq ReadyMix (Sigma), on Bio-Rad Chromo 4 system. Reaction mix in final volume $25 \mu \mathrm{l}$ contained $12.5 \mu \mathrm{l}$ SYBR Green I, $3 \mu \mathrm{l} \mathrm{cDNA}$ and $300 \mathrm{nM}$ of each primer pairs. PCR was carried out under following conditions: $15 \mathrm{sec}$ denaturation at $94^{\circ} \mathrm{C}, 1 \mathrm{~min}$

Table 1. Primer sequences and annealing temperature. LXR - liver X receptor, SREBP - sterol response element binding protein, ACC - acetyl-coenzyme A carboxylase, PPAR - peroxisome proliferator activated receptor, FAT/CD36 - fatty acid translocase/CD36, FABPpm - plasma membraneassociated fatty acid binding protein, HSL - hormone-sensitive lipase, ATGL - adipose triglyceride lipase, DGKろ - diacylglycerol kinase $\zeta$, PAP - phosphatidic acid phosphohydrolase, DGAT - diacylglycerol acyltransferase

\begin{tabular}{|c|c|c|c|}
\hline Gene & & Primer sequence & Annealing temperature \\
\hline $\operatorname{LXR} \alpha$ & $\begin{array}{l}\text { forward } \\
\text { reverse }\end{array}$ & $\begin{array}{l}\text { 5'-TGATGCTGAATTTGCTCTGC-3' } \\
\text { 5'-GGCTCACCAGCTTCATTAGC-3' }\end{array}$ & $57^{\circ} \mathrm{C}$ \\
\hline $\operatorname{LXR} \beta$ & $\begin{array}{l}\text { forward } \\
\text { reverse }\end{array}$ & $\begin{array}{l}\text { 5'-TCTTTCTCCGACCAGCCTAA-3' } \\
5^{\prime} \text {-TCTCGTGGTTGTAGCGTCTG-3' }\end{array}$ & $58^{\circ} \mathrm{C}$ \\
\hline SREBP-1c & $\begin{array}{l}\text { forward } \\
\text { reverse }\end{array}$ & $\begin{array}{l}\text { 5'-GTGGTCTTCCAGAGGCTGAG-3' } \\
\text { 5'-GGGTGAGAGCCTTGAGACAG-3' }\end{array}$ & $60^{\circ} \mathrm{C}$ \\
\hline ACC1 & $\begin{array}{l}\text { forward } \\
\text { reverse }\end{array}$ & $\begin{array}{l}\text { 5'-TACAACGCAGGCATCAGAAG-3' } \\
\text { 5'-TGTGCTGCAGGAAGATTGAC-3' }\end{array}$ & $58^{\circ} \mathrm{C}$ \\
\hline PPAR $\alpha$ & $\begin{array}{l}\text { forward } \\
\text { reverse }\end{array}$ & $\begin{array}{l}\text { 5'-TCACACAATGCAATCCGTTT-3' } \\
\text { 5'-GGCCTTGACCTTGTTCATGT-3' }\end{array}$ & $55^{\circ} \mathrm{C}$ \\
\hline PPAR $\delta$ & $\begin{array}{l}\text { forward } \\
\text { reverse }\end{array}$ & $\begin{array}{l}\text { 5'-AACATCCCCAACTTCAGCAG-3' } \\
\text { 5'-TACTGCGCAAGAACTCATGG-3' }\end{array}$ & $58^{\circ} \mathrm{C}$ \\
\hline FAT/CD36 & $\begin{array}{l}\text { forward } \\
\text { reverse }\end{array}$ & $\begin{array}{l}\text { 5'-GCAACAACAAGGCCAGGTAT-3' } \\
\text { 5'-AAGAGCTAGGCAGCATGGAA-3' }\end{array}$ & $58^{\circ} \mathrm{C}$ \\
\hline FABPpm & $\begin{array}{l}\text { forward } \\
\text { reverse }\end{array}$ & $\begin{array}{l}\text { 5'-TCATCCTTTTGTCTCCAGCTTTT-3' } \\
\text { 5'-CCTATGCCATGCTGACAGGTT-3' }\end{array}$ & $60^{\circ} \mathrm{C}$ \\
\hline HSL & $\begin{array}{l}\text { forward } \\
\text { reverse }\end{array}$ & $\begin{array}{l}\text { 5'-TCTCCCTCTCGTCTGCTG-3' } \\
\text { 5'-TGGTCCTCCGTCTCTGTC -3' }\end{array}$ & $57^{\circ} \mathrm{C}$ \\
\hline ATGL & $\begin{array}{l}\text { forward } \\
\text { reverse }\end{array}$ & $\begin{array}{l}\text { 5'-TCAGACAACTTGCCACTTTATG-3' } \\
\text { 5'-CGAGAGGCGGTAGAGATTG-3' }\end{array}$ & $56^{\circ} \mathrm{C}$ \\
\hline DGKろ & $\begin{array}{l}\text { forward } \\
\text { reverse }\end{array}$ & $\begin{array}{l}\text { 5'-GTGAGTCAGCAGCGTATG-3' } \\
\text { 5'-CTTCGGCAGCATCTTAGC-3' }\end{array}$ & $56^{\circ} \mathrm{C}$ \\
\hline PAP & $\begin{array}{l}\text { forward } \\
\text { reverse }\end{array}$ & $\begin{array}{l}\text { 5'-AACCAGCAACAGACAGAG-3' } \\
\text { 5'-GGCATCCAAGAGGTATAGC-3' }\end{array}$ & $53^{\circ} \mathrm{C}$ \\
\hline DGAT & $\begin{array}{l}\text { forward } \\
\text { reverse }\end{array}$ & $\begin{array}{l}\text { 5'-TGCTCCTACTTTGTGTTATGAACTC-3' } \\
\text { 5'-CTGGATCAGCCCCACTTGAAG-3' }\end{array}$ & $65^{\circ} \mathrm{C}$ \\
\hline$\beta$-actin & $\begin{array}{l}\text { forward } \\
\text { reverse }\end{array}$ & $\begin{array}{l}\text { 5'-CACACCCGCCACCAGTTC-3' } \\
\text { 5'-GTAGGAGTCCTTCTGACCCATAC-3' }\end{array}$ & $63^{\circ} \mathrm{C}$ \\
\hline
\end{tabular}




\section{Cellular Physiology Cell Physiol Biochem 2016;39:350-359 \\ and Biochemistry Published online: June 29, $2016 \quad \begin{aligned} & \text { DOI: 10.1159/000445629 } \\ & \begin{array}{l}\text { c } 2016 \text { The Author(s). Published by S. Karger AG, Basel } \\ \text { www.karger.com/cpb }\end{array}\end{aligned}$ \\ Harasiuk et al.: TO901317 Prevents Diacylglycerols Accumulation in the Diabetic Heart}

annealing at the temperature specific for each primers pair (Table 1), 1 min extension at $72^{\circ} \mathrm{C}$ for 40 cycles. PCR efficiency was examined by serial diluting the template cDNA, and a melt curve was performed after each reaction to verify PCR product specificity. A sample containing no cDNA was used as a negative control to verify the absence of primer dimmers. The results were normalized to $\beta$-actin expression measured in each sample. Relative expression of genes was calculated according to Pfaffl metod [19].

Plasma measurements

Concentration of plasma insulin, glucose, TAG, NEFA and total cholesterol were determined with the use of Rat Insulin ELISA (Mercodia), Glucose Oxidase Reagent Set (Pointe Scientific Inc.), Serum Triacylglycerol Determination Kit (Sigma), Wako NEFA C Kit (Wako Chemicals), and Cholesterol Kit (BioMaxima), respectively.

\section{Statistical analysis}

Data are presented as means \pm SD. Statistical analysis was performed using Statistica 9 (StatSoft). Statistical comparisons between experimental groups were made by using two-way ANOVA followed by Newman-Keuls post hoc test. P values $<0,05$ were considered statistically significant.

\section{Results}

Administration of streptozotocin resulted in increased food intake, reduced weight gain, increased plasma glucose concentration and decreased plasma insulin concentration compared with control animals (Table 2). Treatment with LXR agonist did not induce further changes in these plasma parameters (Table 2). Plasma levels of NEFA, TAG and total cholesterol were not affected either by diabetes or administration of T0901317 (Table 2).

There was an increase in myocardial content of NEFA and TAG in animals with diabetes and their levels were not further affected by administration of T0901317 (Fig. 1). Diabetes decreased the level of phospholipids and ceramide in the heart and there were no further changes after LXR activation (Fig. 1). Treatment with streptozotocin increased myocardial content of DAG, while treatment of diabetic animals with T0901317 resulted in the reduction of DAG in the heart to the level observed in the control group (Fig. 1). The content of myocardial free cholesterol was not affected by diabetes, whereas LXR activation caused a decrease in its content below the value observed in the control and the diabetic group (Fig. 1). There were no statistically significant changes in the amount of cholesterol esters in the heart, either after administration of streptozotocin or T0901317 (Fig. 1).

Streptozotocin administration did not change myocardial mRNA level of LXR $\alpha$, SREBP1c and phosphatidic acid phosphohydrolase (PAP), while T0901317 administration to the diabetic rats elevated expression of these genes (Fig. 2). Diabetes decreased the level of LXR $\beta, A C C 1$, PPAR $\alpha$ and PPAR $\delta$ mRNA in the myocardium compared to the control group

Table 2. Effect of streptozotocin and T091317 treatment on body weight, food intake and plasma measurements in a fed state. The results are means \pm SD $(n=10)$ * significant difference versus control group. STZ - streptozotocin, NEFA - nonesterified fatty acids

\begin{tabular}{lccc}
\hline & Control & STZ & STZ+T091317 \\
\hline Weight gain (g) & $74,77 \pm 21,75$ & $43,76 \pm 14,17^{*}$ & $51,63 \pm 16,71^{*}$ \\
Food intake (g/d/rat) & $38,92 \pm 0,67$ & $61,31 \pm 11,64 *$ & $65,00 \pm 8,18^{*}$ \\
Glucose $(\mathrm{mg} / \mathrm{dl})$ & $156 \pm 17$ & $434 \pm 45^{*}$ & $459 \pm 41^{*}$ \\
Insulin $(\mathrm{ng} / \mathrm{ml})$ & $2,59 \pm 1,09$ & $0,47 \pm 0,21^{*}$ & $0,45 \pm 0,32^{*}$ \\
NEFA $(\mathrm{nmol} / \mathrm{ml})$ & $183 \pm 32$ & $159 \pm 51$ & $184 \pm 75$ \\
Triacylglycerols $(\mathrm{nmol} / \mathrm{ml})$ & $863 \pm 64$ & $746 \pm 365$ & $912 \pm 672$ \\
Total cholesterol $(\mathrm{nmol} / \mathrm{ml})$ & $1650 \pm 363$ & $1495 \pm 271$ & $1894 \pm 474$ \\
\hline
\end{tabular}


Fig. 1. Effect of streptozotocin and T091317 treatment on myocardial content of examined lipids. The results are means \pm SD (n $=10)$. $*$ significant difference versus control group, \# significant difference versus streptozotocin diabetic group. STZ - streptozotocin, NEFA - nonesterified fatty acids.
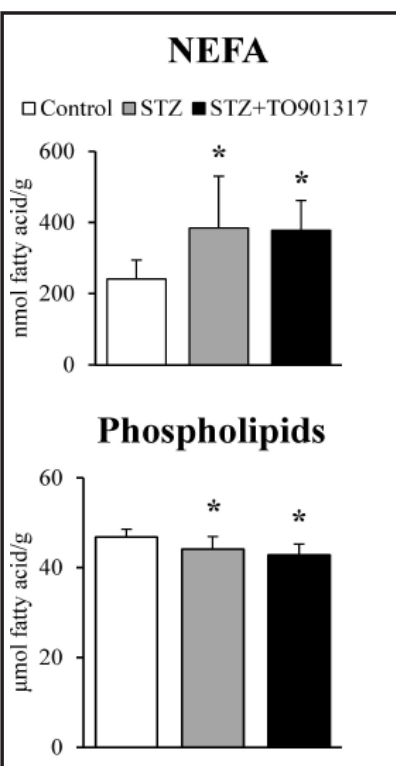

Ceramide

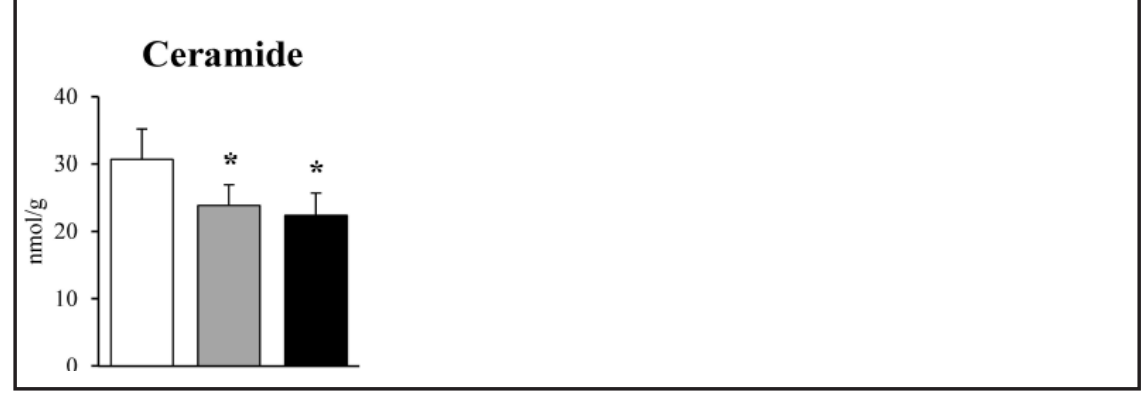

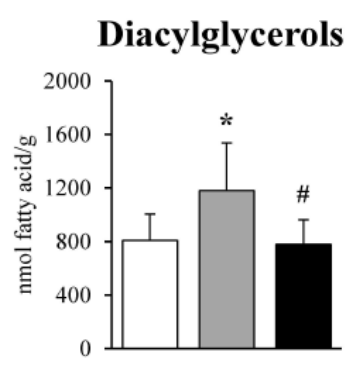

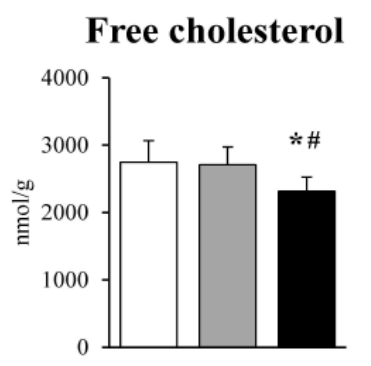

Triacylglycerols

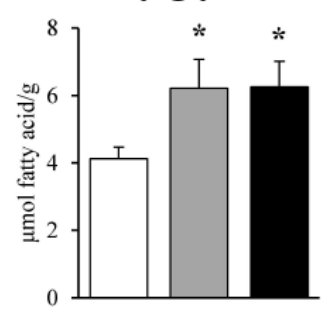

Cholesterol esters

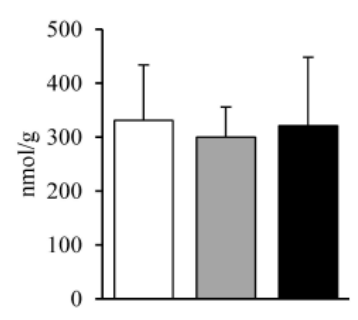

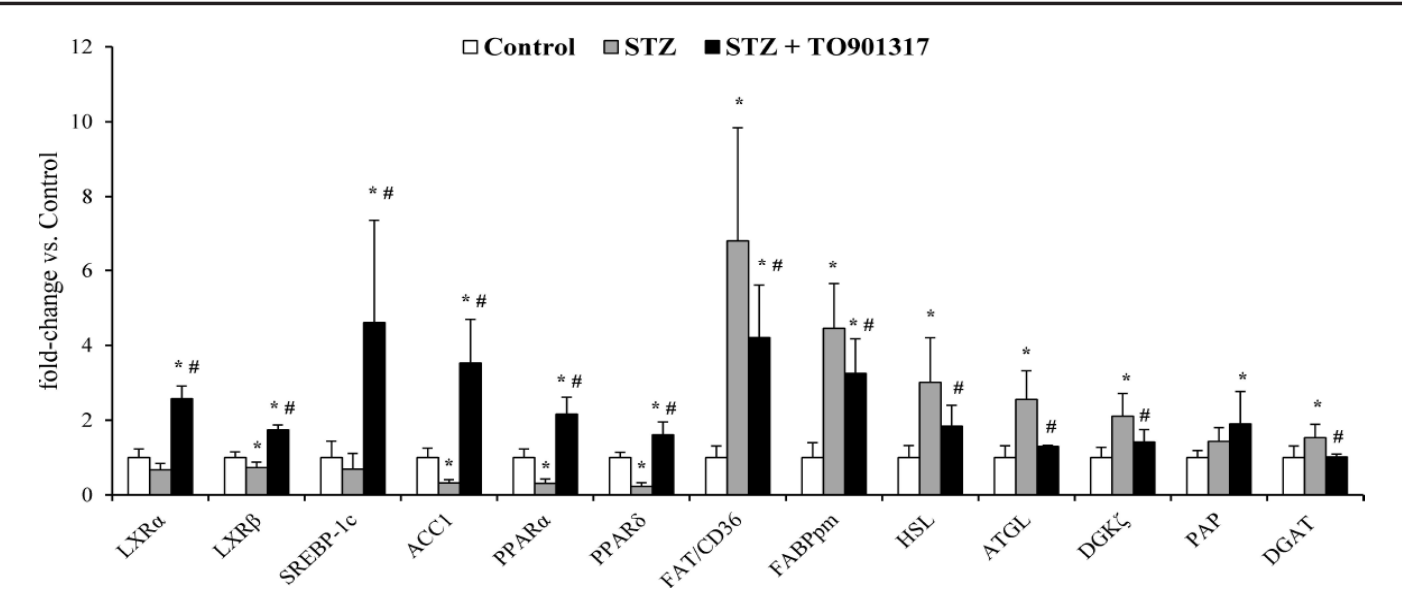

Fig. 2. Effect of streptozotocin and T091317 treatment on mRNA expression of selected genes in the heart. The results are means \pm SD $(n=6)$. ${ }^{*}$ significant difference versus control group, \# significant difference versus streptozotocin diabetic group. STZ - streptozotocin, LXR - liver X receptor, SREBP - sterol response element binding protein, ACC - acetyl-coenzyme A carboxylase, PPAR - peroxisome proliferator activated receptor, FAT/CD36 - fatty acid translocase/CD36, FABPpm - plasma membrane-associated fatty acid binding protein, HSL - hormone-sensitive lipase, ATGL - adipose triglyceride lipase, DGKろ - diacylglycerol kinase $\zeta$, PAP - phosphatidic acid phosphohydrolase, DGAT - diacylglycerol acyltransferase.

(Fig. 2). Expression of LXR $\beta$, ACC1, PPAR $\alpha$ and PPAR $\delta$ was markedly induced by LXR agonist in the hearts of the diabetic animals (Fig. 2). Streptozotocin-diabetes caused an increase in the level of FAT/CD36, FABPpm, hormone-sensitive lipase (HSL), ATGL, diacylglycerol kinase 


\section{Cellular Physiology Cell Physiol Biochem 2016;39:350-359 \\ \begin{tabular}{ll|l} 
and Biochemistry $10.1159 / 000445629$ & $\begin{array}{l}\text { DO } 2016 \text { The Author(s). Published by S. Karger AG, Basel } \\
\text { Published online: June 29, } 2016\end{array}$ \\
\cline { 2 - 2 }
\end{tabular}}

$\zeta$ (DGKろ) and diacylglycerol acyltransferase (DGAT) mRNA in the myocardium. This trend was reversed by T0901317, however, the level of expression FAT/CD36 and FABPpm was still elevated compared to the control group (Fig. 2).

\section{Discussion}

Streptozotocin is a chemical agent used to produce type 1 diabetes in animal model due to selective destruction of $\beta$-islet cells of the pancreas which leads to impaired insulin secretion [20]. In our study, 3 weeks after single injection of streptozotocin, rats showed hypoinsulinemia and hyperglycemia, as expected. However plasma levels of TAG, NEFA and cholesterol were unaffected by diabetes. Treatment with T0901317 had no effect on all above mentioned parameters. In line with our results, other authors also did not observe changes in plasma levels of glucose, insulin, NEFA, cholesterol, or TAG in STZ-diabetic animals after LXR activation with synthetic agonist [21-24]. According to Tachibana et al. [24] serum TAG elevation was not observed after administration of LXR agonist because of insulin deficiency, which may strongly suppress the lipogenic effect of T0901317.

In our previous report [11], we demonstrated that LXR activation with T0901317 does not lead to myocardial lipid accumulation in rats despite increased plasma lipid levels. Hypertriglyceridemia is a well known side effect of synthetic LXR agonists that make it difficult to establish direct effects of LXR activation in the myocardium. In the present study, concentration of plasma lipids was not affected by T0901317, and because of that all changes observed in the heart might be attributed to activation of myocardial LXR.

Our results suggest that STZ-induced diabetes did not cause activation of myocardial LXRs. We observed, that LXR $\alpha$ expression did not change, whereas LXR $\beta$ expression decreased compared to nondiabetic animals. This is in contrast to the results obtained by other authors. Cheng et al. [9] showed that during the 20-week study, LXR $\alpha$ expression gradually increased in the ventricles and atria of STZ-diabetic rats. Wang et al. [25] observed that 5 weeks after injection of streptozotocin mRNA expression of both LXR isoforms was markedly enhanced in the rat heart. Moreover, both authors reported elevation of myocardial expression of LXR target genes: FAT/CD36 and acyl-CoA synthetase (ACSL), which are involved in lipid uptake and storage [9], and ATP-binding cassette transporter A1 (ABCA1), which is involved in reduction of cellular cholesterol content [25]. We also found increase in the level o FAT/ CD36 in the diabetic myocardium, however, mRNA level of other known LXR target genes, SREBP-1c and ACC1 [26], did not increase. SREBP-1c is a transcription factor which binds to sterol response element within the promoter region of genes encoding lipogenic enzymes [3]. ACC1 is a lipogenic enzyme and its expression is regulated directly by LXRs or in SREBP$1 \mathrm{c}$ dependent manner [3]. Finally we did not observe changes in cholesterol content in the diabetic heart which supports our conclusion that LXRs were not activated after injection of streptozotocin. Differences between our results and those obtained by Cheng et al. [9] and Wang et al. [25] might result from different duration of experiments (3-week study vs. 5 or 20 -week study) and/or the type of animal model (Wistar rats vs. Sprague Dawley rats).

Administration of T0901317 activated LXRs in the rat myocardium under streptozotocininduced diabetes conditions. This is confirmed by enhanced expression of LXR $\alpha$ and LXR $\beta$. It has been shown that LXR $\alpha$ expression is controlled by an autoregulatory mechanism. Functional LXRE activated by both LXR isoforms was identified in the human LXR $\alpha$ gene promoter [27]. Synthetic as well as natural LXR agonists increased LXR $\alpha$ expression in human macrophages, adipocytes, hepatocytes, skin fibroblasts and myotubes [15, 28]. Ulven et al. [29] demonstrated the existence of LXR autoregulation in mice, and observed that T0901317 increased the amount of LXR $\alpha$ mRNA in white adipose tissue. Moreover, activation of myocardial LXRs is confirmed also by enhanced expression of their target genes (SREBP$1 \mathrm{c}$ and ACC1) and by lower level of cardiac cholesterol compared to the diabetic group.

Cheng et al. [9] and Wang et al. [25], found significant increase of ABCA1 and ABCG1 protein levels in the heart of diabetic rats. These transporters are responsible for cholesterol 


\section{Cellular Physiology Cell Physiol Biochem 2016;39:350-359 \\ \begin{tabular}{l|l|l}
\hline DOI: 10.1159/000445629 & $\begin{array}{l}\text { (C) 2016 The Author(s). Published by S. Karger AG, Basel } \\
\text { www.karger.com/cpb }\end{array}$
\end{tabular} \\ Harasiuk et al.: TO901317 Prevents Diacylglycerols Accumulation in the Diabetic Heart}

removal from cells [30], and they are under transcriptional regulation by LXRs [31]. Indeed Wang et al. [25] reported decreased content of free cholesterol in the diabetic myocardium. In our study, cardiac free cholesterol level decreased only in the group of animals treated with T0901317, and similarly to the above mentioned authors, it was associated with upregulation of expression of LXRs. Reboulleau et al. [32] also observed that treatment with a cocktail of LXR/RXR agonists (22-hydroxy-cholesterol/9-cis-retinoic acid) induced cholesterol efflux from cultured neonatal rat cardiomyocytes. We have previously found that T0901317 decreases content of free cholesterol in rat skeletal muscles [33], however, not in the myocardium [11]. T0901317 also increased cholesterol efflux in mice myotubes [34, 35], and according to Hessvik et al. [35] LXR $\beta$ plays the dominant role in this process in skeletal muscle. Recently our group showed that LXR $\beta$ is more abundant than LXR $\alpha$ in the rat heart [11], and we speculate that decrease of free cholesterol level observed in the present study was caused mainly by LXR $\beta$ activation.

Accumulation of DAG has been noted in the hearts of STZ-diabetic rats [36, 37]. We have also observed increased myocardial DAG content in diabetic rats compared to the control animals. This increase was prevented by administration of T0901317. In our previous reports $[11,38]$ we observed that LXR activation did not affect the level of DAG in the heart and skeletal muscles in healthy rats as well as in rats fed with high fat diet. DAG is a second messenger which activates protein kinase C (PKC) [39]. PKC is responsible for phosphorylation of many cellular proteins, and thus for modification of their activity $[40,41]$. Activation of DAG-PKC pathway has been recognized as an early and common mechanism leading to cardiac dysfunction and remodeling in STZ diabetes [42, 43]. Bilim et al. [44] demonstrated that cardiac overexpression of DGKל, enzyme controlling cellular DAG levels, prevents STZ-induced diabetic cardiomyopathy in mice. Our results suggest that T0901317 may reverse diabetes-induced changes in the heart, by reducing the content of DAG. The observed change in DAG level did not seem to be caused by alterations in the rate of TAG synthesis, because LXR agonist downregulated expression of DGAT, the enzyme which catalyzes esterification of DAG to TAG [45], and had no effect on expression of PAP, the enzyme involved in de novo DAG synthesis [45]. Enhanced transformation of DAG into phosphatidic acid or monoacylglycerol was also unlikely to be responsible for T0901317induced reduction in DAG level, because mRNA expression of DGKろ (the enzyme converting DAG into phosphatidic acid) [45], and HSL (lipase exhibiting 10-fold higher specific activity for DAG than TAG or monoacylglycerol) [46] was downregulated. However, we found that T0901317 markedly decreased mRNA expression of ATGL, the enzyme which selectively performs the first step of TAG hydrolysis, converting TAG to DAG and free fatty acid [47]. On the basis of the above findings, we speculate that T0901317 reduced DAG level in the diabetic myocardium primarily by downregulation of ATGL expression (and hence production of DAG from TAG), while the accompanying decrease in expression of DGKろ, DGAT, and HSL was likely a compensatory response preventing further reduction in cellular DAG level.

Reduced content of DAG could be also a consequence of T0901317-induced increase in expression of myocardial PPAR $\alpha$ and PPAR $\delta$. PPARs are nuclear transcription factors, and their major function in the heart is to provide energy by regulating expression of genes involved in fatty acids metabolism [48]. Expression of PPAR $\alpha$ may be induced by LXR through the LXRE present in its promoter region [49]. Myocardial expression of PPAR $\alpha$ and PPAR $\delta$ genes is down-regulated in streptozotocin diabetic rats [50-53] which is in agreement with our observations. Interestingly, in our study administration of T0901317 reversed these changes. It is possible that T0901317 enhances fatty acid $\beta$-oxidation in a PPAR-dependent manner, and thus protects cardiomyocytes against accumulation of DAG, lipid considered to be toxic. Baranowski et al. [33] observed that T0901317 stimulates fatty oxidation in rat skeletal muscle, most likely via upregulation of PPAR $\delta$.

Moreover, LXR agonist decreased myocardial expression of FAT/CD36 and FABPpm, genes encoding proteins involved in fatty acid uptake and transport across the sarcolemma [54]. Luiken et al. [54] demonstrated that an increase in expression of these genes is followed by an increase in fatty acid transport in the STZ-diabetic heart. There is a possibility that 


\section{Cellular Physiology Cell Physiol Biochem 2016;39:350-359

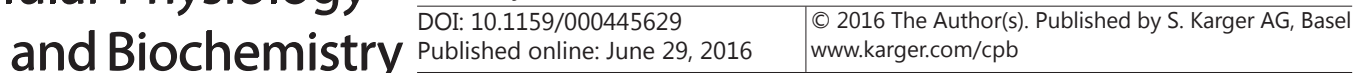 \\ Harasiuk et al.: TO901317 Prevents Diacylglycerols Accumulation in the Diabetic Heart}

T0901317 reduces fatty acid uptake in cardiomyocytes of diabetic rats which, in addition to increased fatty acid oxidation, could also contribute to decreased DAG level observed in our study.

In our previous report [11] we investigated the effect of T0901317 (the dose and treatment duration were the same as in the present study) on lipid metabolism in the myocardium of healthy rats. In the above study T0901317 reduced the level of ceramide and cholesterol esters and increased TAG content in the heart. Contrary to the healthy animals, LXR activation in diabetic rats did not affect the myocardial level of ceramide, cholesterol esters or TAG. However, the content of DAG and free cholesterol was decreased, which suggests that the latter effects of T0901317 are specific for the STZ-diabetic heart. Furthermore, myocardial mRNA expression of PPAR and LXR isoforms was upregulated in response to LXR activation only in the diabetic rats. These findings strongly suggest that insulin deficiency modifies the response of the heart to synthetic LXR agonist.

In summary, we observed accumulation of NEFA, DAG and triacylglycerols in the heart of STZ-diabetic rats. Administration of T0901317 to these animals increased myocardial expression of both LXR isoforms and their target genes. LXR activation did not affect the content of examined myocardial lipid classes, except cholesterol and DAG which were reduced. We conclude, that T0901317 prevents DAG accumulation in diabetic heart. We speculate that reduction of DAG content in the myocardium is related to changes in expression of PPARs (upregulation), ATGL and fatty acid transporters (downregulation).

\section{Acknowledgements}

This work was supported by the Medical University of Białystok (grants no. 144-18511L and 154-18690L).

\section{Disclosure Statement}

None declared.

\section{References}

1 Nuclear Receptors Nomenclature Committee: A unified nomenclature system for the nuclear receptor superfamily. Cell 1999;97:161-163.

2 Zhang Y, Mangelsdorf DJ: Luxuries of lipid homeostasis: The unity of nuclear hormone receptors, transcription regulation, and cholesterol sensing. Mol Interv 2002;2:78-87.

3 Bełtowski J: Liver x receptors (lxr) as therapeutic targets in dyslipidemia. Cardiovasc Ther 2008;26:297316.

4 Janowski BA, Grogan MJ, Jones SA, Wisely GB, Kliewer SA, Corey EJ, Mangelsdorf DJ: Structural requirements of ligands for the oxysterol liver x receptors lxralpha and lxrbeta. Proc Natl Acad Sci USA 1999;96:266-271.

5 Ulven SM, Dalen KT, Gustafsson JA, Nebb HI: Lxr is crucial in lipid metabolism. Prostaglandins Leukot Essent Fatty Acids 2005;73:59-63.

6 Schultz JR, Tu H, Luk A, Repa JJ, Medina JC, Li L, Schwendner S, Wang S, Thoolen M, Mangelsdorf DJ, Lustig KD, Shan B: Role of lxrs in control of lipogenesis. Genes Dev 2000;14:2831-2838.

7 Liang G, Yang J, Horton JD, Hammer RE, Goldstein JL, Brown MS: Diminished hepatic response to fasting/ refeeding and liver $x$ receptor agonists in mice with selective deficiency of sterol regulatory elementbinding protein-1c. J Biol Chem 2002;277:9520-9528.

8 Wu S, Yin R, Ernest R, Li Y, Zhelyabovska O, Luo J, Yang Y, Yang Q: Liver x receptors are negative regulators of cardiac hypertrophy via suppressing nf-kappab signalling. Cardiovasc Res 2009;84:119-126.

9 Cheng Y, Liu G, Pan Q, Guo S, Yang X: Elevated expression of liver x receptor alpha (lxr $\alpha$ ) in myocardium of streptozotocin-induced diabetic rats. Inflammation 2011;34:698-706. 


\section{Cellular Physiology Cell Physiol Biochem 2016;39:350-359 \begin{tabular}{c|c|c|c|} 
DOI: 10.1159/000445629 & O 2016 The Author(s). Published by S. Karger AG, Basel \\
wwww.karger.com/cpb
\end{tabular}

10 Lei P, Baysa A, Nebb HI, Valen G, Skomedal T, Osnes JB, Yang Z, Haugen F: Activation of liver x receptors in the heart leads to accumulation of intracellular lipids and attenuation of ischemia-reperfusion injury. Basic Res Cardiol 2013;108:323.

11 Harasiuk D, Baranowski M, Zabielski P, Chabowski A, Górski J: Lxr agonist t0901317-induced hyperlipidemia does not lead to lipid accumulation in the rat heart. Cell Physiol Biochem 2015;35:10951106.

12 Bayeva M, Sawicki KT, Ardehali H: Taking diabetes to heart--deregulation of myocardial lipid metabolism in diabetic cardiomyopathy. J Am Heart Assoc 2013;2:e000433.

13 Rodrigues B, Cam MC, McNeill JH: Metabolic disturbances in diabetic cardiomyopathy. Mol Cell Biochem 1998;180:53-57.

14 Young ME, McNulty P, Taegtmeyer H: Adaptation and maladaptation of the heart in diabetes: Part ii: Potential mechanisms. Circulation 2002;105:1861-1870.

15 Baranowski M: Biological role of liver x receptors. J Physiol Pharmacol 2008;59 Suppl 7:31-55.

16 Roemen TH, van der Vusse GJ: Application of silica gel column chromatography in the assessment of nonesterified fatty acids and phosphoglycerides in myocardial tissue. J Chromatogr 1985;344:304-308.

17 Nawrocki A, Górski J: Effect of plasma free fatty acid concentration on the content and composition of the free fatty acid fraction in rat skeletal muscles. Horm Metab Res 2004;36:601-606.

18 Baranowski M, Zabielski P, Blachnio A, Gorski J: Effect of exercise duration on ceramide metabolism in the rat heart. Acta Physiol (Oxf) 2008;192:519-529.

19 Pfaffl MW: A new mathematical model for relative quantification in real-time rt-pcr. Nucleic Acids Res 2001;29:e45.

20 Patel R, Shervington A, Pariente JA, Martinez-Burgos MA, Salido GM, Adeghate E, Singh J: Mechanism of exocrine pancreatic insufficiency in streptozotocin-induced type 1 diabetes mellitus. Ann N Y Acad Sci 2006;1084:71-88.

21 Montanaro MA, González MS, Bernasconi AM, Brenner RR: Role of liver x receptor, insulin and peroxisome proliferator activated receptor alpha on in vivo desaturase modulation of unsaturated fatty acid biosynthesis. Lipids 2007;42:197-210.

22 Cermenati G, Giatti S, Cavaletti G, Bianchi R, Maschi O, Pesaresi M, Abbiati F, Volonterio A, Saez E, Caruso D, Melcangi RC, Mitro N: Activation of the liver x receptor increases neuroactive steroid levels and protects from diabetes-induced peripheral neuropathy. J Neurosci 2010;30:11896-11901.

23 Sodhi RK, Singh N: Liver x receptor agonist t0901317 reduces neuropathological changes and improves memory in mouse models of experimental dementia. Eur J Pharmacol 2014;732:50-59.

24 Tachibana H, Ogawa D, Matsushita Y, Bruemmer D, Wada J, Teshigawara S, Eguchi J, Sato-Horiguchi C, Uchida HA, Shikata K, Makino H: Activation of liver x receptor inhibits osteopontin and ameliorates diabetic nephropathy. J Am Soc Nephrol 2012;23:1835-1846.

25 Wang XT, Li J, Liu L, Hu N, Jin S, Liu C, Mei D, Liu XD: Tissue cholesterol content alterations in streptozotocin-induced diabetic rats. Acta Pharmacol Sin 2012;33:909-917.

26 Talukdar S, Hillgartner FB: The mechanism mediating the activation of acetyl-coenzyme a carboxylasealpha gene transcription by the liver x receptor agonist t0-901317. J Lipid Res 2006;47:2451-2461.

27 Li Y, Bolten C, Bhat BG, Woodring-Dietz J, Li S, Prayaga SK, Xia C, Lala DS: Induction of human liver x receptor alpha gene expression via an autoregulatory loop mechanism. Mol Endocrinol 2002;16:506-514.

28 Cozzone D, Debard C, Dif N, Ricard N, Disse E, Vouillarmet J, Rabasa-Lhoret R, Laville M, Pruneau D, Rieusset J, Lefai E, Vidal H: Activation of liver x receptors promotes lipid accumulation but does not alter insulin action in human skeletal muscle cells. Diabetologia 2006;49:990-999.

29 Ulven SM, Dalen KT, Gustafsson JA, Nebb HI: Tissue-specific autoregulation of the lxralpha gene facilitates induction of apoe in mouse adipose tissue. J Lipid Res 2004;45:2052-2062.

30 Oram JF, Vaughan AM: Atp-binding cassette cholesterol transporters and cardiovascular disease. Circ Res 2006;99:1031-1043.

31 Allahverdian S, Pannu PS, Francis GA: Contribution of monocyte-derived macrophages and smooth muscle cells to arterial foam cell formation. Cardiovasc Res 2012;95:165-172.

32 Reboulleau A, Robert V, Vedie B, Doublet A, Grynberg A, Paul JL, Fournier N: Involvement of cholesterol efflux pathway in the control of cardiomyocytes cholesterol homeostasis. J Mol Cell Cardiol 2012;53:196205. 


\section{Cellular Physiology Cell Physiol Biochem 2016;39:350-359 \begin{tabular}{c|c|c|c|} 
DOI: 10.1159/000445629 & O 2016 The Author(s). Published by S. Karger AG, Basel \\
wwww.karger.com/cpb
\end{tabular}}

Harasiuk et al.: TO901317 Prevents Diacylglycerols Accumulation in the Diabetic Heart

33 Baranowski M, Blachnio-Zabielska AU, Zabielski P, Harasim E, Harasiuk D, Chabowski A, Gorski J: Liver x receptor agonist t0901317 enhanced peroxisome proliferator-activated receptor-delta expression and fatty acid oxidation in rat skeletal muscle. J Physiol Pharmacol 2013;64:289-297.

34 Muscat GE, Wagner BL, Hou J, Tangirala RK, Bischoff ED, Rohde P, Petrowski M, Li J, Shao G, Macondray G, Schulman IG: Regulation of cholesterol homeostasis and lipid metabolism in skeletal muscle by liver $\mathrm{x}$ receptors. J Biol Chem 2002;277:40722-40728.

35 Hessvik NP, Boekschoten MV, Baltzersen MA, Kersten S, Xu X, Andersén H, Rustan AC, Thoresen GH: Lxr\{beta\} is the dominant lxr subtype in skeletal muscle regulating lipogenesis and cholesterol efflux. Am J Physiol Endocrinol Metab 2010;298:E602-613.

36 Nawrocki A, Górska M, Wójcik B, Busłowska A: Effect of streptozotocin diabetes on fatty acid content and composition of the heart lipids in the rat. Rocz Akad Med Bialymst 1999;44:170-179.

37 Hayashi K, Okumura K, Matsui H, Murase K, Kamiya H, Saburi Y, Numaguchi Y, Toki Y, Hayakawa T: Involvement of 1,2-diacylglycerol in improvement of heart function by etomoxir in diabetic rats. Life Sci 2001;68:1515-1526.

38 Baranowski M, Zabielski P, Błachnio-Zabielska AU, Harasim E, Chabowski A, Górski J: Insulin-sensitizing effect of lxr agonist t0901317 in high-fat fed rats is associated with restored muscle glut4 expression and insulin-stimulated as160 phosphorylation. Cell Physiol Biochem 2014;33:1047-1057.

39 Newton AC: Protein kinase c: Poised to signal. Am J Physiol Endocrinol Metab 2010;298:E395-402.

40 Nishizuka Y: Protein kinase c and lipid signaling for sustained cellular responses. FASEB J 1995;9:484-496.

41 Mellor H, Parker PJ: The extended protein kinase c superfamily. Biochem J 1998;332:281-292.

42 Kang N, Alexander G, Park JK, Maasch C, Buchwalow I, Luft FC, Haller H: Differential expression of protein kinase $\mathrm{c}$ isoforms in streptozotocin-induced diabetic rats. Kidney Int 1999;56:1737-1750.

43 Arikawa E, Ma RC, Isshiki K, Luptak I, He Z, Yasuda Y, Maeno Y, Patti ME, Weir GC, Harris RA, Zammit VA, Tian R, King GL: Effects of insulin replacements, inhibitors of angiotensin, and pkcbeta's actions to normalize cardiac gene expression and fuel metabolism in diabetic rats. Diabetes 2007;56:1410-1420.

44 Bilim 0, Takeishi Y, Kitahara T, Arimoto T, Niizeki T, Sasaki T, Goto K, Kubota I: Diacylglycerol kinase zeta inhibits myocardial atrophy and restores cardiac dysfunction in streptozotocin-induced diabetes mellitus. Cardiovasc Diabetol 2008;7:2.

45 Carrasco S, Mérida I: Diacylglycerol, when simplicity becomes complex. Trends Biochem Sci 2007;32:2736.

46 Haemmerle G, Zimmermann R, Hayn M, Theussl C, Waeg G, Wagner E, Sattler W, Magin TM, Wagner EF, Zechner R: Hormone-sensitive lipase deficiency in mice causes diglyceride accumulation in adipose tissue, muscle, and testis. J Biol Chem 2002;277:4806-4815.

47 Gao H, Feng XJ, Li ZM, Li M, Gao S, He YH, Wang JJ, Zeng SY, Liu XP, Huang XY, Chen SR, Liu PQ: Downregulation of adipose triglyceride lipase promotes cardiomyocyte hypertrophy by triggering the accumulation of ceramides. Arch Biochem Biophys 2015;565:76-88.

48 Huss JM, Kelly DP: Nuclear receptor signaling and cardiac energetics. Circ Res 2004;95:568-578.

49 Colin S, Bourguignon E, Boullay AB, Tousaint JJ, Huet S, Caira F, Staels B, Lestavel S, Lobaccaro JM, Delerive $\mathrm{P}$ : Intestine-specific regulation of pparalpha gene transcription by liver $\mathrm{x}$ receptors. Endocrinology 2008;149:5128-5135.

50 Depre C, Young ME, Ying J, Ahuja HS, Han Q Garza N, Davies PJ, Taegtmeyer H: Streptozotocin-induced changes in cardiac gene expression in the absence of severe contractile dysfunction. J Mol Cell Cardiol 2000;32:985-996.

51 Young ME, Patil S, Ying J, Depre C, Ahuja HS, Shipley GL, Stepkowski SM, Davies PJ, Taegtmeyer H: Uncoupling protein 3 transcription is regulated by peroxisome proliferator-activated receptor (alpha) in the adult rodent heart. FASEB J 2001;15:833-845.

52 Yu BC, Chang CK, Ou HY, Cheng KC, Cheng JT: Decrease of peroxisome proliferator-activated receptor delta expression in cardiomyopathy of streptozotocin-induced diabetic rats. Cardiovasc Res 2008;80:78-87.

53 Lee TI, Kao YH, Chen YC, Pan NH, Chen YJ: Oxidative stress and inflammation modulate peroxisome proliferator-activated receptors with regional discrepancy in diabetic heart. Eur J Clin Invest 2010;40:692699.

54 Luiken JJ, Arumugam Y, Bell RC, Calles-Escandon J, Tandon NN, Glatz JF, Bonen A: Changes in fatty acid transport and transporters are related to the severity of insulin deficiency. Am J Physiol Endocrinol Metab 2002;283:E612-621. 